Original Contribution

\title{
SEASONAL ACTIVITY OF THE HORSE FLIES (DIPTERA, TABANIDAE) FROM THE CENTRAL BALKAN MOUNTAINS, BULGARIA
}

\author{
D. Ganeva*, Iv. Ivanov \\ Department of Biology and Aquaculture, Faculty of Agriculture, Trakia University, \\ Stara Zagora, Bulgaria
}

\begin{abstract}
The seasonal activity of the tabanids (Diptera: Tabanidae) was studied from May to September (20102011) in three localities on the territory of the Central Balkan Mountains. A total of 2232 specimens from 25 tabanid species and 8 genera were collected and processed. The first horse flies emerge in the first half of May and the last specimens were collected until mid-September. The tabanids reached their highest peak abundance in the first half of July. The most abundant species of the tabanid assemblages in the Central Balkan Mountains were Tabanus tergestinus Egg. (56.73 \%), Tabanus bromius L. (12.71\%) and Haematopota pluvialis L. (8.87\%). The largest number of specimens of $T$. tergestinus was collected during the peak of the seasonal abundance of horse flies on the territory of the Central Balkan Mountains.
\end{abstract}

Key words: tabanids, seasonal activity, dominant species, Central Balkan Mountains, Bulgaria

\section{INTRODUCTION}

The tabanids are poikilothermic organisms and their activity is influenced by the temperature of the environment. Emergence of the tabanids and fluctuations of their seasonal abundance depends on the geographical latitude and altitude of the area and the specific set of meteorological factors that offers each biotope. Data on parameters of the tabanids' seasonal abundance in Bulgaria have been published by (1, 2 and 3-6). Many regions of Bulgaria have still not been studied with respect to the species composition of the tabanid assemblages or the dynamics of their activity. Due to this lack of data, the purpose of the present study was to investigate the fluctuations of the seasonal abundance of the tabanids on the territory of the Central Balkan Mountains. This study was a part of the research, conducted on the fauna and activity of the horse flies from the Central Balkan Mountains. As a result of the study on the composition of the tabanid fauna from the

\footnotetext{
*Correspondence to: Diana Ganeva, Department of Biology and Aquaculture, Faculty of Agriculture, Trakia University, Student Campus, 6000 Stara Zagora, Bulgaria; Tel.: (+359) 42699 324, Fax:(+359) 422780 66; d_ganeva2000@yahoo.com
}

studied area (7) reported 28 species from 9 genera.

\section{MATERIALS AND METHODS}

The Central Stara Planina (Central Balkan Mountains) is the longest of the three sections of Stara Planina. It was situated between the Botevgrad Pass and Vratnik Pass. The climate is moderately continental, except for the most eastern parts of the mountain. The maximum of precipitation is in the months of May and June, while the minimum is in February. Spring and summer are cool, while autumn is characterized by higher daily temperatures than those in spring. The average January temperatures of the air vary between $-2^{\circ} \mathrm{C}$ and $-4^{\circ} \mathrm{C}$ in the low and middle mountain zones. This determines the duration of the snow cover from 3 to 6 months (8).

The study on the fluctuations of the seasonal abundance of the tabanids was carried out in three localities on the territory of the Central Balkan Mountains from May to September during 2010 and 2011. The biotopes are situated on the southern side of the Central Stara Planina.

The Panitsite place (749 $\mathrm{m}$ a.s.l.) was situated at $6 \mathrm{~km}$ from the north of the city of Kalofer. 
GANEVA D., et al.

The tabanids were collected in a biotope situated at the south of a nearby livestock breeding farm. The chosen biotope is a meadow surrounded to the west and east by a deciduous forest. At a distance of about $100 \mathrm{~m}$ from the meadow, in the ravine that has formed there, flows the river Byala Reka.

The village of Enina (537 $\mathrm{m}$ a.s.1.) is situated at $4 \mathrm{~km}$ northeast of the city of Kazanlak, at the foot of Stara Planina. The biotope is situated at $2 \mathrm{~km}$ northeast of the village of Enina. At about $50 \mathrm{~m}$ south of this biotope, next to the road from Kazanlak to Gorno Izvorovo, there is a fountain used for watering livestock raised in the region. The vegetation consists of grass, bushes and deciduous trees.

The village of Gorno Izvorovo (643 $\mathrm{m}$ a.s.1) is situated at $12 \mathrm{~km}$ northeast of the city of Kazanlak. Field observations were conducted on a pasture located at $1.5 \mathrm{~km}$ from the south of the village. At the north of the pasture there is an untilled land covered with grassy vegetation, and at the west, the pasture borders on a coniferous forest. Near the studied biotope there is a micro dam (at a distance of $500 \mathrm{~m}$ ).

\section{Sampling and processing of specimens}

The horse flies were collected monthly by sweep net from 8 a.m. to 8 p.m. in the studied biotopes. During the research period, 2232 specimens (2163 и 69仓) of tabanids were captured and identified. The processing of the insects was carried out in the laboratory. The collected specimens were determined according to the keys of (9-10).

A list of the studied localities is presented. The list of the localities indicates the altitude, the geographic coordinates, the collection dates and the total number of collected specimens from each locality. Altitude and geographical coordinates were obtained through measurement with Garmin GPS Navigator Etrex VistaHCx.

The degree of similarity between tabanid assemblages in the studied biotopes has been determined by Sörensen's similarity index (11):

$$
\mathrm{S}=\frac{2 \mathrm{c}}{\mathrm{a}+\mathrm{b}} \times 100, \text { where }
$$

a - the number of species during the first year of the study,

$\mathrm{b}$ - the number of species in the second year of the study $\mathrm{c}$ - the number of species common to the years in the studied biotopes

\section{List of localities}

1. Place „Panitsite”, 749 м, 42.661 N, 24.981 E: 13.06.2010, 80; 11.07.2010, 54 ; 31.07.2010, $7 q ;$ 7.08.2010, $49 \bigcirc ;$ 28.08.2010, $3 \bigcirc ;$ 9.07.2011, $223 \bigcirc$; 7.08.2011, 11 ㅇ․

2. Enina village, $\mathbf{5 3 7} \mathbf{~ M , ~} 42.395$ $\mathrm{N}, 25.261$ E: 16.05.2010, $7 \bigcirc ;$ 29.05.2010, $3 \circ$, $3 \bigcirc$; 16.06.2010, $15 \circ$; 27.06.2010, $45 \circ, 1 \bigcirc$; 17.07.2010, 83 +, $7 \delta^{\lambda} ; \mathbf{1 . 0 8 . 2 0 1 0 , 1 0 0}$, $3{ }^{\uparrow}$; 14.08.2010, $21+, 8$; $29.08 .2010,3 q$;

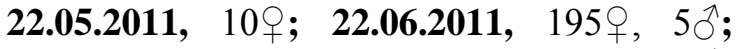
1.07.2011, $1 q ；$ 16.07.2011, 28 $q, 15 \overbrace{}^{\top}$;

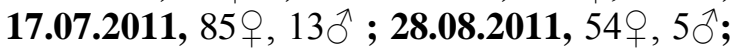
11.09.2011, 10 우.

3. Gorno Izvorovo village, 643 M, $42.390 \mathrm{~N} ; 25.283$ E: 16.05.2010, 42q; 29.05.2010, $25 \circ$; 17.06.2010, $12 \circ$; 3.07.2010, $114 \bigcirc$; 18.07.2010, 91 , $4{ }^{\uparrow}$; 2.08.2010, $13 \bigcirc$; 15.08.2010, 86 \% 10 ; $\quad$ 21.05.2011, $98 \%$; 23.06.2011， 262 q, $1 \delta^{\uparrow} ;$ 16.07.2011, 233ㅇ; 14.08.2011, 93 ㅇ, $3{ }^{\lambda} ;$ 11.09.2011, 7 우

\section{RESULTS AND DISCUSSION}

As a result of the study, it was ascertained that the tabanids on the territory of Central Balkan Mountains become active in the month of May, but show a seasonal difference in the parameters of their activity both in one and the same biotope in the two years of research (2010-2011) and across the different biotopes that were studied. That is why, in this section, separate analyses were presented of the seasonal activity of tabanids in the studied biotopes; then the obtained data were generalized.

\section{Seasonal abundance of tabanids in Panitsite locality}

In the locality of Panitsite the tabanids began flying at the end of May and beginning of June and were active until the end of August at latest. In the course of the study different beginning dates of tabanid activity were registered in the region. In 2010 they began flying at the end of May, and in 2011, about a month later than in the previous year (Figure 1). The main cause for this later start of activity in 2011 was the unfavourable meteorological conditions (rain, wind and low temperatures) in the months of May and June that year. The influence of low temperatures and poor precipitation upon the time of the tabanids' first appearance has been commented 
GANEVA D., et al.

on by various authors (12-14). According to (12), the amount of heat needed for the development of the larvae and pupae was the most important of all meteorological factors that might change the timeline of the appearance of tabanids. (13) emphasizes the complex impact of low temperatures and meager precipitation upon the time of the appearance of the imago. He stresses that these two factors definitely delay its appearance, while (14) points out that the variations of meteorological factors in various years have a significant impact upon the start, duration, and peak of tabanid activity.

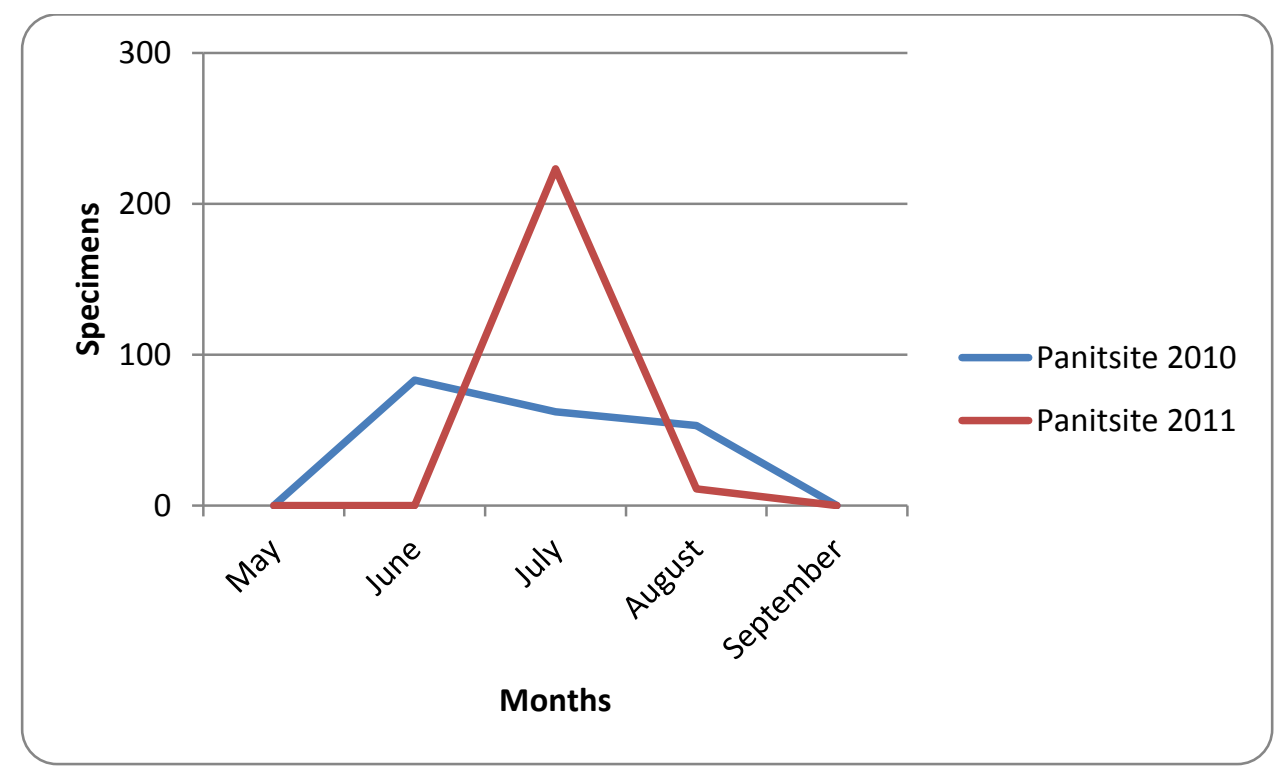

Figure 1. Seasonal abundance of tabanids in the locality Panitsite (2010-2011)

As a result of the study, it has been found that the massive activization of the tabanids in 2010 happened in June (for 8 of the total 10 species registered in that season), and in 2011, in the month of July (for 7 species out of the total 9 in that season) (Table 1). In 2010 the tabanids reached their maximum of seasonal activity in the middle of June (13.06.), and in 2011, in the first half of July (9.07.) (Figure 1). The curves of seasonal dynamics of the tabanid's numbers in the studied locality (Figure 1) clearly indicate the differences between the two active seasons (2010 and 2011) as regards the kind of fluctuations of activity level within each period of the flight. After the mass-scale beginning of flight and attainment of the maximum abundance on 13.6.2010, there was a gradual decrease of activity, unlike in the year 2011 (Figure 1). The tabanid activity in 2011 was characterized by a sharp increase in numbers of specimens (223 specimens out of a total of 243 for the whole season), which marked a peak in their abundance for that year (9.07.), followed by a steep decline in their activity in August (Figure 1). In the months of September in both active seasons (11.9.2010; 18.9.2011) there was no registered tabanid activity, despite the suitable meteorological conditions (sunny weather, mild south-eastern winds, and a temperature of $24-27^{\circ} \mathrm{C}$ ).

The registered peaks in abundance of tabanids were due to the activity of the basic dominant species in the coenosis, i.e., T. tergestinus (Table 1). The population of T.tergestinus had outstandingly high abundance in both active tabanid periods in the locality Panitsite, but these were higher in 2011, when 198 specimens of this species were caught at the time of the general seasonal maximum in numbers of tabanids. This species amounted to $88.79 \%$ of all captured specimens during the peak of the seasonal activity of tabanids (9.07.2011) (Figure 1). In 2010 the population of T.tergestinus in the studied locality amounted to $79.52 \%$ of the total numbers of the tabanids coenosis during the seasonal peak of abundance (Figure 1). On this basis, we may conclude that the population of T.tergestinus plays a decisive role in the formation of the general activity of the tabanids in the studied biotope, while the dynamics of this species' seasonal abundance in the two years defines the character of the dynamics of seasonal activity of the tabanids in the region. 
GANEVA D., et al.

Analysis of the dynamics of seasonal activity of tabanids shows that the two active seasons (2010-2011) are similar in terms of the composition of the coenosis (similarity index $73.68 \%$ ), but differ with regard to the duration of the active period of tabanids, with regard to the nature of the change of activity within a season, and with regard to the maximum of seasonal abundance in the two years (Figure 1).

Table 1. Species composition and number of collected specimens of tabanids in the locality Panitsite, Kalofer ( 2010-2011)

\begin{tabular}{|c|c|c|c|c|c|c|}
\hline \multirow[b]{2}{*}{ Species } & \multicolumn{2}{|c|}{ Panitsite 2010 } & \multicolumn{2}{|c|}{ Panitsite 2011} & \multicolumn{2}{|c|}{ Total } \\
\hline & $\begin{array}{l}\text { Number } \\
\text { of } \\
\text { specimens }\end{array}$ & $\begin{array}{l}\text { RA, } \\
\%\end{array}$ & $\begin{array}{l}\text { Number } \\
\text { of } \\
\text { specimens }\end{array}$ & RA, \% & $\begin{array}{l}\text { Number } \\
\text { of } \\
\text { specimens }\end{array}$ & RA, \% \\
\hline Atylotus loewianus (Villeneuve, 1920) & $\mathbf{3 5} q$ & 18.13 & $7 q$ & 2.99 & $\mathbf{4 2}$ 우 & 9.84 \\
\hline $\begin{array}{l}\text { Hybomitra distinguenda (Verrall, } \\
\text { 1909) }\end{array}$ & 2 우 & 1.04 & - & - & 2 우 & 0.47 \\
\hline $\begin{array}{l}\text { Tabanus autumnalis } \\
\text { Linnaeus, } 1761\end{array}$ & 1 우 & 0.52 & - & - & 1 우 & 0.23 \\
\hline T. bromius Linnaeus, 1758 & 129 & 6.22 & 10 우 & 4.28 & 229 & 5.15 \\
\hline T. glaucopis Meigen, 1820 & 9 9우 & 4.66 & 29 & 0.85 & 11 19 & 2.58 \\
\hline $\begin{array}{l}\text { T. maculicornis } \\
\text { Zetterstedt, } 1842\end{array}$ & 6 우 & 3.11 & 7 우 & 2.99 & 13 ㅇ & 3.04 \\
\hline T. quatuornutatus Meigen, 1820 & 19 & 0.52 & - & - & 19 & 0.23 \\
\hline T. sudeticus Zeller, 1842 & - & - & 29 & 0.85 & 29 & 0.47 \\
\hline T. tergestinus Egger, 1859 & $121+9$ & 62.69 & $199+9$ & 85.04 & 320 우 & 74.95 \\
\hline T. unifasciatus Loew, 1858 & - & - & 19 & 0.43 & 19 & 0.23 \\
\hline $\begin{array}{l}\text { Haematopota pluvialis } \\
\text { (Linnaeus, 1758) }\end{array}$ & 5 우 & 2.59 & 2 우 & 0.85 & 7 우 & 1.64 \\
\hline Philipomyia graeca (Fabricius, 1794) & 19 & 0.52 & 49 & 1.72 & 5 우 & 1.17 \\
\hline Total number of specimens & 193 우 & $100 \%$ & $\mathbf{2 3 4}+$ & $100 \%$ & 427우 & $100 \%$ \\
\hline Total number of species & $\mathbf{1 0}$ & & 9 & & 12 & \\
\hline
\end{tabular}

The registered peaks in abundance of tabanids were due to the activity of the basic dominant species in the coenosis, i.e., T. tergestinus (Table 1). The population of T.tergestinus had outstandingly high abundance in both active tabanid periods in the locality Panitsite, but these were higher in 2011, when 198 specimens of this species were caught at the time of the general seasonal maximum in numbers of tabanids. This species amounted to $88.79 \%$ of all captured specimens during the peak of seasonal activity of tabanids (9.07.2011) (Figure 1). In 2010 the population of T.tergestinus in the studied locality amounted to $79.52 \%$ of the total numbers of the tabanids coenosis during the seasonal peak of abundance (Figure 1). On this basis, we may conclude that the population of T.tergestinus plays a decisive role in the formation of the general activity of the tabanids in the studied biotope, while the dynamics of this species' seasonal abundance in the two years defines the character of the dynamics of seasonal activity of the tabanids in the region.

Analysis of the dynamics of seasonal activity of tabanids shows that the two active seasons (2010-2011) are similar in terms of the composition of the coenosis (similarity index $73.68 \%$ ), but differ with regard to the duration of the active period of tabanids, with regard to the nature of the change of activity within a season, and with regard to the maximum of seasonal abundance in the two years (Figure 1).

On the basis of the discussion above, it may be generalized that the tabanids in the locality Panitsite become active at the end of May and beginning of June, and fly no later than the end of August, while the peak of their seasonal abundance occurs in the first half of July (Figure 2). The highest degree of activity during the peak of seasonal abundance is displayed by the dominant species in the coenosis, T.tergestinus (Table 1). 


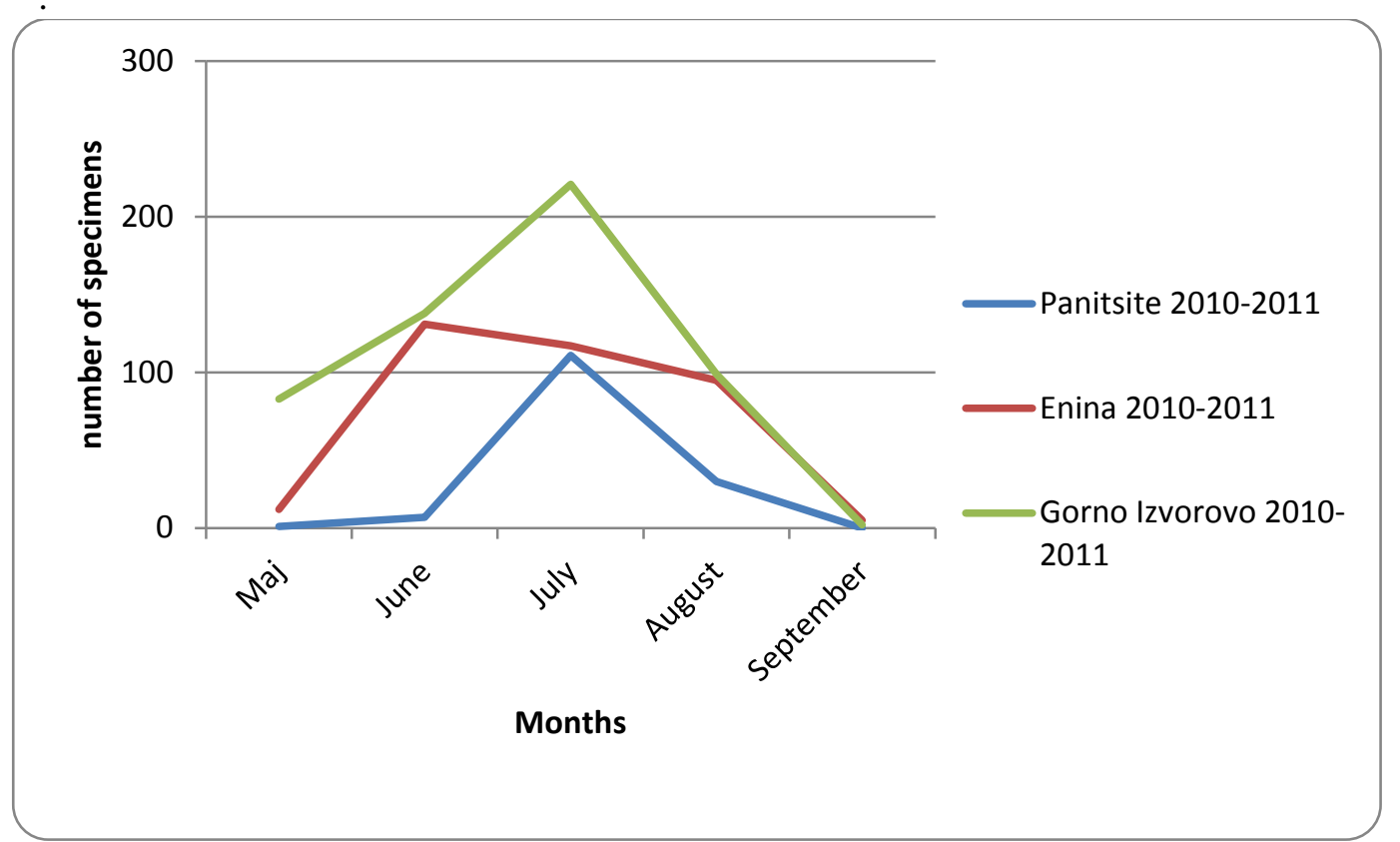

Figure 2. Seasonal abundance of tabanids on the teritory of the Central Balkan Mountains (average data by localities)

Seasonal abundance of tabanids in Enina locality

In the biotope near the village of Enina, tabanids become active, under favourable meteorological conditions, during the second half of May, and they fly until the middle of September. Their active period in 2010 began with a gradual increase in activity, attained a maximum in the beginning of August, after which the tabanid activity sharply declined, and zero activity was registered in September (Figure 3). The peak of seasonal abundance of tabanids in the biotope near Enina was due to the flight of 7 species of tabanids out of a total of 17 species registered in that season (Table 2).

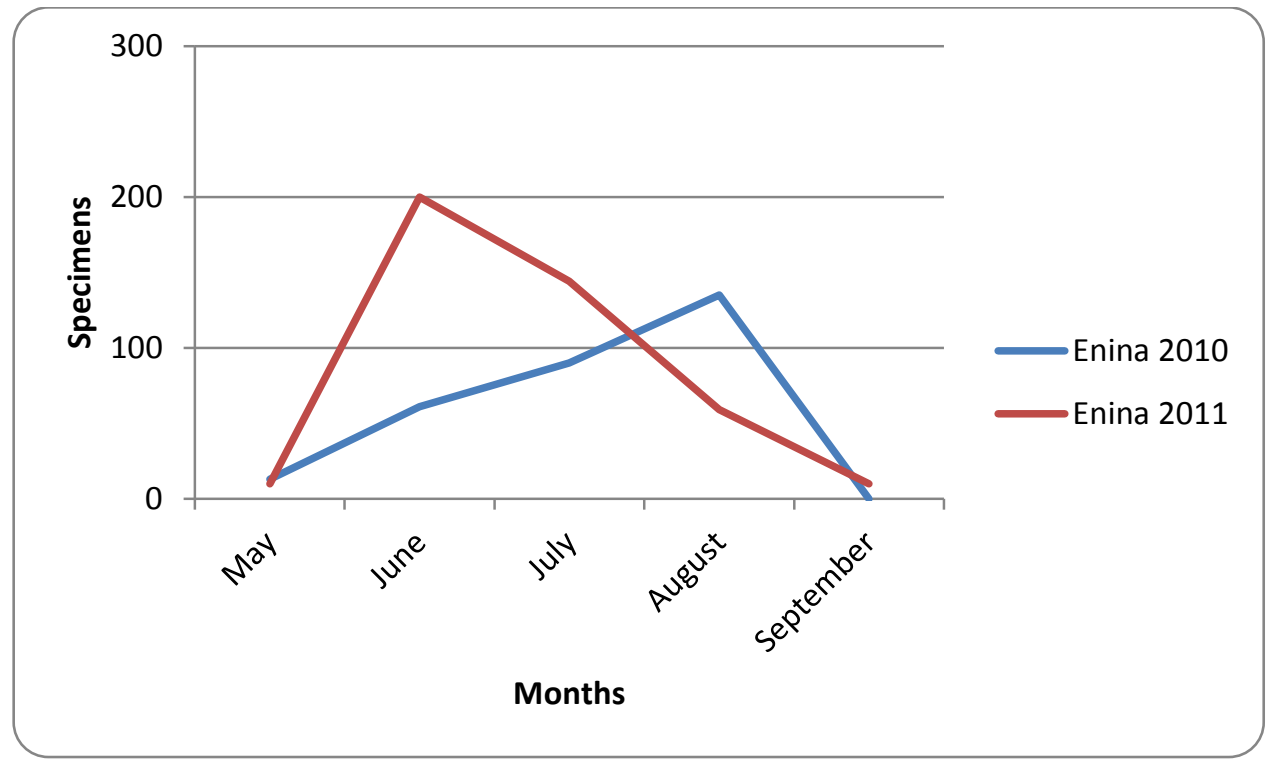

Figure 3. Seasonal abundance of tabanids in the locality Enina (2010-2011)

In 2011, the dynamics of activity was of a opposite character. It began with the appearance of 2 species (Haematopota pluvialis and Tabanus quatuornutatus), but in a very short time 9 more species became active, and in the second half of June a maximum of seasonal abundance was registered. The latter was due to the activity of 11 species of tabanids out of a total of 17 species registered in that year's season. After this peak, tabanid activity gradually decreased, but unlike in the year 2010, it continued in 
GANEVA D., et al.

September as well, when flight were registered only of the species Haematopota grandis. The index of similarity in the tabanid coenosis in the two years was $94.12 \%$.

Table 2. Species composition and number of collected specimens of tabanids in the locality Enina (2010-2011)

\begin{tabular}{|c|c|c|c|c|c|c|}
\hline \multirow[b]{2}{*}{ Species } & \multicolumn{2}{|c|}{ Enina 2010} & \multicolumn{2}{|c|}{ Enina 2011} & \multicolumn{2}{|c|}{ Total } \\
\hline & $\begin{array}{l}\text { Number of } \\
\text { specimens }\end{array}$ & $\underset{\%}{\mathbf{R A}}$ & $\begin{array}{l}\text { Number of } \\
\text { specimens }\end{array}$ & $\underset{\%}{\mathbf{R A}}$ & $\begin{array}{l}\text { Number of } \\
\text { specimens }\end{array}$ & $\underset{\%}{\mathbf{R A}}$ \\
\hline $\begin{array}{l}\text { Chrysops viduatus (Fabricius, } \\
1794 \text { ) }\end{array}$ & $1 q$ & 0.33 & 1 & 0.23 & 29 & 0.28 \\
\hline $\begin{array}{l}\text { Atylotus loewianus } \\
\text { (Villeneuve, 1920) }\end{array}$ & 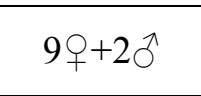 & 3.68 & $5 q$ & 1.19 & $14 q+2 \widehat{\jmath}$ & 2.22 \\
\hline $\begin{array}{l}\text { Hybomitra ciureai (Séguy, } \\
1937 \text { ) }\end{array}$ & 19 & 0.33 & 29 & 0.48 & $3 q$ & 0.42 \\
\hline $\begin{array}{l}\text { Tabanus autumnalis } \\
\text { Linnaeus, } 1761\end{array}$ & $1 q+1 \lesssim$ & 0.68 & $2 \hat{\sigma}$ & 0.48 & $1 q+3 \precsim$ & 0.56 \\
\hline T. bromius Linnaeus, 1758 & $\mathbf{3 6}+\mathbf{+ 1 0} \overbrace{}^{\lambda}$ & 15.38 & $\mathbf{5 1} q+\mathbf{2} \curvearrowright$ & 12.59 & $\mathbf{8 7} q+\mathbf{1 2} \precsim$ & 13.75 \\
\hline T. cordiger Meigen, 1820 & $2 q$ & 0.68 & $2 q$ & 0.48 & 49 & 0.56 \\
\hline T. glaucopis Meigen, 1820 & 19 & 0.33 & 19 & 0.23 & 29 & 0.28 \\
\hline $\begin{array}{l}\text { T. maculicornis Zetterstedt, } \\
1842\end{array}$ & 29 & 0.68 & 69 & 1.43 & 89 & 1.11 \\
\hline $\begin{array}{l}\text { T. quatuornutatus Meigen, } \\
1820\end{array}$ & $7 q+4 \lesssim$ & 3.68 & $3 q$ & 0.71 & $10 q+4 \widehat{\jmath}$ & 1.93 \\
\hline T. regularis Jaennicke, 1866 & $1 \sigma^{\top}$ & 0.33 & $2 q+4{ }^{\lambda}$ & 1.43 & $29+5 \lesssim$ & 0.97 \\
\hline $\begin{array}{l}\text { T. rupium (Brauer in Brauer } \\
\text { and Bergenstamm, 1880) }\end{array}$ & 19 & 0.33 & 19 & 0.23 & 29 & 0.28 \\
\hline T. sudeticus Zeller, 1842 & 49 & 1.34 & 69 & 1.43 & 109 & 1.39 \\
\hline T. tergestinus Egger, 1859 & $\mathbf{1 9 8}+\mathbf{+ 3} \curvearrowright$ & 67.22 & $\mathbf{2 3 3}+\mathbf{+ 1 7} \precsim$ & 59.38 & $\mathbf{4 3 1}+\mathbf{+ 2 0} \overbrace{}^{\lambda}$ & 62.64 \\
\hline T. unifasciatus Loew, 1858 & $3 q+1 \lesssim$ & 1.34 & $5 q+5 \AA$ & 2.38 & $8++6 \overbrace{}^{\lambda}$ & 1.94 \\
\hline $\begin{array}{l}\text { Haematopota grandis } \\
\text { Meigen, } 1820\end{array}$ & 19 & 0.33 & $42 q+5 \hat{\jmath}$ & 11.16 & $43 q+5 \widehat{\jmath}$ & 6.67 \\
\hline H. pluvialis (Linnaeus, 1758) & 59 & 1.67 & $22 q+3 \overbrace{}^{\lambda}$ & 5.94 & $27 q+3 ð$ & 4.17 \\
\hline $\begin{array}{l}\text { Dasyrhamphis ater (Rossi, } \\
1790)\end{array}$ & - & - & $1+$ & 0.23 & 19 & 0.14 \\
\hline $\begin{array}{l}\text { Philipomyia graeca } \\
\text { (Fabricius, 1794) }\end{array}$ & 59 & 1.67 & - & - & $5 q$ & 0.69 \\
\hline Total number of specimens & $277 \bigcirc+22 \lesssim$ & $100 \%$ & $\mathbf{3 8 3} q+\mathbf{3 8} \overbrace{}^{\lambda}$ & $100 \%$ & $660 \bigcirc+60 \curvearrowright$ & $100 \%$ \\
\hline Total number of species & 17 & & 17 & & 18 & \\
\hline
\end{tabular}

Analysis of the obtained data indicates that in a seasonal aspect, the peak of the abundance of tabanids in the biotope Enina also varied during the two active seasons (2010-2011) (Figure 3). The maximum of seasonal numbers of tabanids in 2010 was registered at the beginning of August (1.08.), while in the year 2011, in the second half of June (22.06.) (Figure 3). The variation in time of the peak of seasonal abundance was due to the specific features of meteorological factors (temperature and humidity) in the studied biotope during the whole active season and also at the time of collecting in the field (cloudy weather, with changeable north wind in June and July of 2010, and sunny, warm and comparatively calm weather in June and July 2011).

The maximum in the seasonal abundance of tabanids in both years was due, again, to the mass flight of the dominant species in this region, i.e., T.tergestinus (Table 2). A smaller place was held by the second dominant species for this region, T.bromius (Table 2). 
In view of the above-mentioned, it may be generalized that the tabanids in the region of the village of Enina become active in the second half of May and fly until the middle of September, reaching a peak of seasonal abundance in the second half of June (Figure 2).

\section{Seasonal abundance of tabanids in Gorno Izvorovo locality}

In the region of the village of Gorno Izvorovo, it was found that the tabanids started flying in the first half of May (Figure 4); in the second
GANEVA D., et al. half of May was registered high activity of $H$. pluvialis and T.quatuornutatus during both flight seasons in this region. The massive activity of tabanids in the year 2010 was in the month of July (12 species were flying, out of the total 18 registered in that season), while in the year 2011, it was in the month of June (with 11 species active out of the 19 registered in that season) (Figure 4, Table 3). The index of similarity of the tabanids coenosis during these two active seasons is $70.27 \%$.

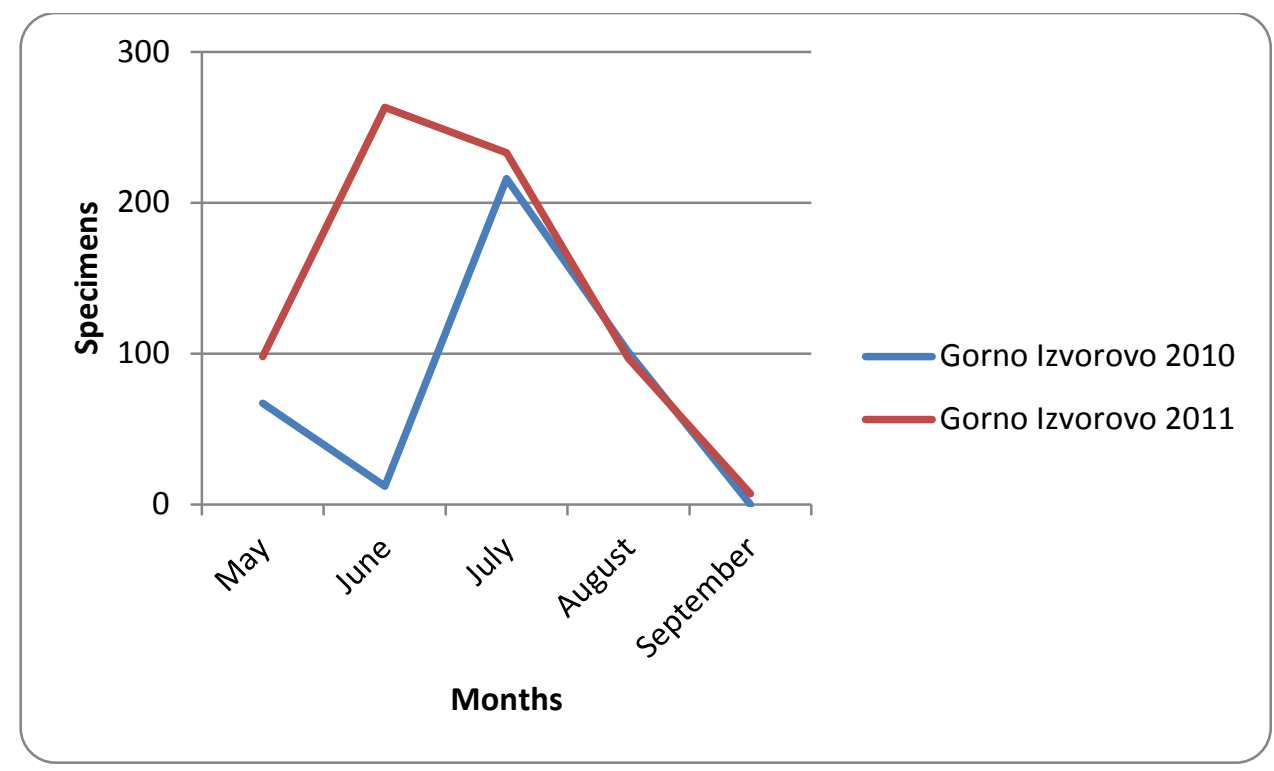

Figure 4. Seasonal abundance of tabanids in the locality Gorno Izvorovo (2010-2011)

The tabanids' active season in 2011 continued into September when the activity of the latesummer species T.glaucopis and H.grandis was registered (11.9.2011). At that same time, two specimens of H.longeantennata were captured. This species was announced for the first time, as a new one to the Bulgarian fauna, in the region of the village of Oryahovitsa (28.05.1992)(4). During the present study, a new location of this species in Bulgaria is announced, and the end of its active season is indicated.

After processing the quantitative data from the two years of the study, it was found that the maximum in the seasonal number of tabanids in the region varies from the second half of June (in 2011) to the second half of July (in 2010) (Figure 4). As in the two previous biotopes, in the region of Gorno Izvorovo, the main cause of the difference in the time of seasonal activity maximum was similarly the variation in values of meteorological factors across the season and at the times of collecting in the field. The quantitative data from collections in the field indicate that in both years the main part was that of T.tergestinus. The population of this species provides from $64.35 \%$ (2010) to $82.83 \%$ (2011) of the activity of the tabanids coenosis at the time of the maximum of seasonal numbers.

The graphical expression of the summarized data on the seasonal dynamics of the number of tabanids in the biotope of the village of Gorno Izvorovo was a single-peak curve with a peak in the first half of July (Figure 2), which was a result of the mass flight of the dominant species in this region, T.tergestinus and T.bromius. During the maximum in the seasonal number, the leading dominant species T.tergestinus, has the highest activity, whose specimens (332) represent $73.94 \%$ of all flies caught during this period of the tabanids' active season. 
GANEVA D., et al.

Table 3. Species composition and number of collected specimens of tabanids in the locality Gorno Izvorovo (2010-2011)

\begin{tabular}{|c|c|c|c|c|c|c|}
\hline \multirow[b]{2}{*}{ Species } & \multicolumn{2}{|c|}{$\begin{array}{c}\text { Gorno Izvorovo } \\
2010 \\
\end{array}$} & \multicolumn{2}{|c|}{$\begin{array}{c}\text { Gorno Izvorovo } \\
2011 \\
\end{array}$} & \multicolumn{2}{|c|}{ Total } \\
\hline & $\begin{array}{l}\text { Number of } \\
\text { specimens }\end{array}$ & $\underset{\%}{\mathbf{R A},}$ & $\begin{array}{l}\text { Number of } \\
\text { specimens }\end{array}$ & $\underset{\%}{\mathbf{R A},}$ & $\begin{array}{l}\text { Number of } \\
\text { specimens }\end{array}$ & $\underset{\%}{\mathbf{R A}}$ \\
\hline $\begin{array}{l}\text { Chrysops caecutiens } \\
\text { (Linnaeus, 1758) }\end{array}$ & 1 운 & 0.26 & - & - & 1 우 & 0.09 \\
\hline C. viduatus (Fabricius, 1794) & - & - & 1 우 & 0.14 & 1 운 & 0.09 \\
\hline $\begin{array}{l}\text { Atylotus loewianus } \\
\text { (Villeneuve, 1920) }\end{array}$ & 40 우 & 10.31 & 109 & 1.43 & 509 & 4.61 \\
\hline $\begin{array}{l}\text { Therioplectes gigas (Herbst, } \\
\text { 1787) }\end{array}$ & - & - & 19 & 0.14 & 19 & 0.09 \\
\hline $\begin{array}{l}\text { Hybomitra ciureai (Séguy, } \\
\text { 1937) }\end{array}$ & 1 우 & 0.26 & 8 q & 1.16 & 9 우 & 0.83 \\
\hline $\begin{array}{l}\text { H. distinguenda (Verrall, } \\
\text { 1909) }\end{array}$ & $2 q$ & 0.51 & $4 q$ & 0.57 & 6 우 & 0.55 \\
\hline $\begin{array}{l}\text { Tabanus autumnalis Linnaeus, } \\
1761\end{array}$ & $1+$ & 0.26 & 1 우 & 0.14 & 2 우 & 0.18 \\
\hline T. bovinus Linnaeus, 1758 & $1+$ & 0.26 & - & - & 19 & 0.09 \\
\hline T. bromius Linnaeus, 1758 & 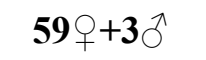 & 15.98 & $\mathbf{1 1 5} q+\mathbf{3} \overbrace{}^{\lambda}$ & 16.93 & $\mathbf{1 7 4}++\mathbf{6} \bigcirc^{\lambda}$ & 16.59 \\
\hline T. cordiger Meigen, 1820 & 29 & 0.51 & 19 & 0.14 & $3 q$ & 0.28 \\
\hline T. glaucopis Meigen, 1820 & - & - & $3 q$ & 0.44 & 3 운 & 0.28 \\
\hline $\begin{array}{l}\text { T. maculicornis Zetterstedt, } \\
1842\end{array}$ & 3 우 & 0.77 & - & - & 3 우 & 0.28 \\
\hline $\begin{array}{l}\text { T. miki (Brauer in Brauer and } \\
\text { Bergenstamm, 1880) }\end{array}$ & 1 운 & 0.26 & - & - & 1 우 & 0.09 \\
\hline $\begin{array}{l}\text { T. quatuornutatus Meigen, } \\
1820\end{array}$ & $14 ㅇ$ & 3.61 & 28 ㅇ & 4.02 & $42 q$ & 3.87 \\
\hline T. regularis Jaennicke, 1866 & $10^{\lambda}$ & 0.26 & 29 & 0.29 & $2 q+10^{\lambda}$ & 0.28 \\
\hline $\begin{array}{l}\text { T. rupium (Brauer in Brauer } \\
\text { and Bergenstamm, 1880) }\end{array}$ & 19 & 0.26 & - & - & 19 & 0.09 \\
\hline T. sudeticus Zeller, 1842 & 19 & 0.26 & 8 우 & 1.16 & 99 & 0.83 \\
\hline T. tergestinus Egger, 1859 & $167++1 \delta^{\lambda}$ & 43.30 & $\mathbf{4 0 1}$ 운 & $\mathbf{5 7 . 5 3}$ & $\mathbf{5 6 8}++1 \bigcirc^{\wedge}$ & 52.44 \\
\hline T. unifasciatus Loew, 1858 & $5 q$ & 1.29 & $6 q+10^{\lambda}$ & 1.00 & $11++1 \delta^{\lambda}$ & 1.11 \\
\hline $\begin{array}{l}\text { Haematopota grandis Meigen, } \\
1820\end{array}$ & - & - & $4 ㅇ$ & 0.57 & $4 ㅇ$ & 0.37 \\
\hline H. italica Meigen, 1804 & $2 q$ & 0.51 & 1 우 & 0.14 & 3 우 & 0.28 \\
\hline $\begin{array}{l}\text { H. longeantennata (Olsufjev, } \\
\text { 1937) }\end{array}$ & - & - & 29 & 0.29 & 2 ㅇ & 0.18 \\
\hline H. pluvialis (Linnaeus, 1758) & 82 82운 & 21.13 & 96 96 & 13.77 & 178 ? & 16.41 \\
\hline $\begin{array}{l}\text { Philipomyia graeca } \\
\text { (Fabricius, 1794) }\end{array}$ & - & 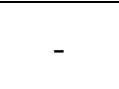 & 1 우 & 0.14 & 1 우 & 0.09 \\
\hline Total number of specimens & $\mathbf{3 8 3} q+\mathbf{5}{ }^{\wedge}$ & $100 \%$ & $693 q+4{ }^{\lambda}$ & $100 \%$ & 1076 $9+9 \AA$ & $100 \%$ \\
\hline Total number of species & 18 & & 19 & & 24 & \\
\hline
\end{tabular}

Of the three biotopes in Central Stara Planina where regular registration in the field was carried out, only in the region of the village of Gorno Izvorovo high activity of H.pluvialis has been established. This is the third dominant species in the tabanids' coenosis in the studied biotope. H.pluvialis is a polyseasonal species, whose activity, according to literary data, goes on from May to September. Our studies have ascertained the active period of this species goes on from the first half of May until the end of August, with a maximum in numbers in the second half of May. 
Analysing the dynamics of seasonal activity of tabanids in the region of Gorno Izvorovo, we may conclude that they become active in the first half of May and fly until the middle of September, with a peak in the first half of July (Figure 2).

\section{CONCLUSIONS}

On the basis of the analysis of the dynamics of tabanid activity in the three localities in the Central Balkan Mountains, it may be concluded that, under favourable meteorological conditions, the tabanids in the region become active in the first half of May and fly until the middle of September, with a peak in the first half of July.

During the active period of tabanids in the Central Balkan Mountains, the populations of T.tergestinus (56.73), T.bromius (12.71\%) and H.pluvialis $(8.87 \%)$ have the highest numbers, and during the maximum in their seasonal abundance in the region, the most active was the attack of T.tergestinus (73.94\%).

In the seasonal aspect, a change of the mass species in the tabanid coenosis of the Central Balkan Mountains has been established. The main appearance of the tabanid coenosis in May and June was determined by the earlysummer species T.quatuornotatus, and the polyseasonal T.tergestinus and H.pluvialis; in July - by the polyseasonal T.tergestinus and T.bromius, and the summer species T.maculicornis, T.sudeticus and T.unifasciatus; in August, by the late-summer species A.loewianus and T.glaucopis.

\section{REFERENCES}

1. Drensky, P., Blood-sucking flies of fam. Tabanidae (obody) in Bulgaria. Bull Roy Inst Nat Sc., Sofia, 2: 55-128, 1929. (In Bulgarian, German summary)

2. Triphonov, T., Pachev, S. and Meshkov, S., Species composition, seasonal dynamics and distribution of Tabanidae in SouthEastern Bulgaria. Veterinary Medicine (Sofia), 1 (3): 47-60, 1964. (In Bulgarian, English summary)

3. Ganeva, D., Seasonal prevalence and daily activity of tabanids (Tabanidae, Diptera) in the Stara Zagora district. Acta entomol bulg, 1: 6-14, 1995. (in Bulgarian, English summary).
GANEVA D., et al.

4. Ganeva, D., Fauna, phenology and activity of blood sucking tabanids (Tabanidae, Diptera) in Stara Zagora Region. $\mathrm{PhD}$, Trakia University, Stara Zagora, Bulgaria, 1-215, 1998. (In Bulgarian English abstract).

5. Ganeva, D., Seasonal activity of Tabanus bromius L., Tabanus tergestinus Egg. and Haematopota pluvialis L. in Stara Zagora District. Acta zool bulg 53 (1): 89-96, 2001.

6. Ganeva, D., Seasonal dynamics of the activity of Tabanus exclusus Pand., Tabanus quatuornotatus Mg. and Philipomyia graeca F. (Diptera, Tabanidae) in Stara Zagora Region, South Bulgaria. Ecology and future, 7 (2): 71-75, 2008. (in Bulgarian, English summary)

7. Ganeva, D. and Ivanov I., Species composition and zoogeographical aspects of the horsefly fauna (Diptera: Tabanidae) in the Central Balkan Mountains Acta zool bulg, 67 (2): 215-222, 2015.

8. Nikolov, V. and Yordanova, M., The Mountains in Bulgaria. Acad Publ House Prof Marin Drinov. Sofia, 2002. (in Bulgarian, English summary).

9. Chvála, M., Lyneborg, L. and Moucha, J., The Horse Flies of Europe (Diptera, Tabanidae). Entomol Soc of Copenhagen, Copenhagen, 1972.

10.Olsufjev, N., Familly Tabanidae. In: Skarlato O, (ed). Fauna SSSR. Insecta, Diptera. Leningrad, 7 (2), pp 1-434, 1977. (In Russian)

11.Sörensen, T., A method of establishing groups of equal amplitude in plant sociology based on similarity of species content. Kongelige Danske Videnskabernes Selskab, Biol krifter 5(4):1-34, 1948.

12.Skufyin, K., Materials on the ecology of horseflies (Diptera, Tabanidae) of the Voronezh region. Coll of zool parazitol works, 22-83, 1966. (In Russian)

13.Auroi, Ch., Les Tabanidae (Diptera) de la Tourbiele du Cachot (Jura Neucatelois). II. Phenologie et abundance annuele. B Soc Neuch Sc Nat, 106: 61-71, 1983.

14.Krčmar, S., Seasonal abundance of horse flies (Diptera: Tabanidae) from two locations in eastern Croatia. J Vector Ecol, 30: 316-321, 2005. 